\title{
Inheritance of Yellow-flesh Intensity in Diploid Potatoes
}

\author{
Kathleen G. Haynes ${ }^{1}$ \\ U.S. Department of Agriculture, Agricultural Research Service, Vegetable Laboratory, Beltsville, MD 20705
}

\begin{abstract}
AdDitional INDEX wORDs. Solanum phureja ssp. phureja, S. stenotomum ssp. stenotomum, narrow-sense heritability, carotenoids

Abstract. Although potato (Solanum tuberosum L.) tuber yellow flesh per se is known to be controlled by a single gene, the intensity of yellow flesh varies widely in Solanum L. species. Many diploid species have very intense yellow flesh, as compared to the commercial tetraploid yellow-flesh cultivar 'Yukon Gold'. Inheritance of yellow-flesh intensity at the diploid level was investigated in a hybrid population of $S$. phureja ssp. phureja (Juz. \& Buk.)-S. stenotomum ssp. stenotomum (Juz. \& Buk.) (PHU-STN). Six randomly chosen male parents were crossed to five randomly chosen female parents in a Design II mating scheme. In 1993, $\approx 12$ progeny (clones) from each of the 30 families were planted in a randomized complete block design with two replications in Presque Isle, Maine, and evaluated for tuber yellow-flesh intensity as measured by a reflectance colorimeter. Twenty-five tubers from each plot were scored using the YI E-313 yellow intensity scale. An average YI E-313 score was obtained for each plot. Narrow-sense heritability on a plot mean basis was estimated as 0.99 with a $\mathrm{SE}$ of 0.65 to 0.72 . There were significant differences among clones within a family. Results suggest that rapid progress can be made in breeding for intense yellow flesh in this diploid population. Clones from this population that produce $2 n$ gametes represent an important source of germplasm for enhancing the intensity of the yellow-flesh trait in tetraploid potatoes.
\end{abstract}

Several yellow-flesh potato cultivars have been developed and released in the United States and Canada in the last 20 years: 'Delta Gold' (Reeves et al., 1980), 'Michigold' (Chase et al., 1992), 'Norwis' (Cipar et al., 1990), 'Red Gold' (Coffin et al., 1987), 'Rose Gold' (Coffin et al., 1988), 'Saginaw Gold' (Coffin et al., 1989) and 'Yukon Gold' (Johnston and Rowberry, 1981). 'Yukon Gold' is the yellow-flesh cultivar that has received the greatest acceptance by U.S. consumers. More seed acres of 'Yukon Gold' were certified in the United States and Canada in 1997 than all other yellow-flesh cultivars combined (National Potato Council, 1998).

Marketers agree that development of yellow-flesh cultivars in the United States need not lead to displacement of, nor competition with, more traditional red, russet, or white-skinned U.S. cultivars (Zink, 1996). The interest in yellow-flesh potatoes among U.S. consumers is due to a number of factors, including their perceived improved taste, better cooking quality, and higher nutritional value. Since the inclusion of potatoes in the Plant Variety Protection Act of 1994, a number of European companies have also introduced their patented cultivars, the majority of which are yellow fleshed, to the United States for trial evaluations and are involved heavily in marketing activities.

The yellow-flesh trait in potatoes is thought to be controlled by a single, dominant gene (Fruwirth, 1912), which has been mapped to the third chromosome (Bonierbale et al., 1988). However, because of the variation in yellow-flesh intensity that has been observed in segregating populations, several researchers have suggested that modifying genes are also important (Black, 1930; Engel, 1957; Schick, 1956). The concentration of color-imparting carotenoids differs greatly in potato clones; however, lutein

Received for publication 26 Feb. 1999. Accepted for publication 23 Aug. 1999 Mention of a trademark, warranty, proprietary product, or vendor does not constitute a guarantee by the U.S. Department of Agriculture and does not imply its approval to the exclusion of other products or vendors that may also be suitable. The cost of publishing this paper was defrayed in part by the payment of page charges. Under postal regulations, this paper therefore must be hereby marked advertisement solely to indicate this fact.

'E-mail: khaynes@asrr.arsusda.gov. and violaxanthin have been identified as major carotenoids in yellow-flesh potatoes (Iwanzik et al., 1983), and, lutein and zeaxanthin have been identified as major carotenoids in orangeflesh potatoes (Brown et al., 1993). Over 500 carotenoids have been identified ; however, all carotenoids originate from a single, common precursor, phytoene (Gross, 1991).

Nongenetic factors are also important in expression of yellowflesh intensity. Within a given tetraploid clone, Haynes et al. (1994) found a negative correlation between yellow-flesh intensity and tuber weight. They suggested that sampling the middle $50 \%$ of tubers, based on weight, was as informative as the full sample for determining yellow-flesh intensity and preserving the consistency of pairwise comparisons between individual clones and a given standard. In additional work, Haynes et al. (1996) reported that the clone $\times$ environment interaction for yellow-flesh intensity in tetraploid potatoes, although statistically significant, was probably too small to be of practical importance. The six environments in which the yellow-flesh clones were evaluated in their study were quite different. They obtained an estimate of broad-sense heritability for yellow-flesh intensity of 0.93 (Haynes et al., 1996). This suggests that yellow-flesh intensity in tetraploid potatoes can be evaluated satisfactorily in one location.

The diploid potato species Solanum phureja is the source of yellow-flesh color in 'Red Gold', 'Rose Gold' and 'Yukon Gold' (Coffin et al., 1987, 1988; Johnston and Rowberry, 1981). Thus, the potential of Solanum phureja to enhance yellow flesh in tetraploid Solanum tuberosum has been demonstrated. Beginning in 1966, Haynes (1972) began a breeding program to adapt a hybrid diploid population of $S$. phureja-S. stenotomum (PHUSTN) to the long day growing conditions present in the United States. Seventy-two plant introductions were eventually included in this random mating population. This population has been evaluated extensively for specific gravity (Haynes and Haynes, 1990; Haynes et al., 1989, 1995). However, no selections were made within this population for tuber flesh color. Therefore, the purpose of this study was to estimate narrow-sense heritability for intensity of yellow-flesh color in a diploid hybrid population of S. phureja-S. stenotomum. 


\section{Materials and Methods}

Twenty clones were randomly selected as parents for this study from a diploid hybrid PHU-STN population. These clones were planted in the greenhouse during Spring 1991 and crosses were attempted in all combinations. True seed were harvested $\approx 6$ to 8 weeks after pollination and resulted in enough seed for a Design II factorial design (Comstock and Robinson, 1948) consisting of six male parents crossed to each of five different female parents. True seed from these 30 families ( 5 females $\times 6$ males) were treated with $1500 \mathrm{mg} \cdot \mathrm{L}^{-1}$ gibberellic acid and sown in a greenhouse in Beltsville, Md., August 1991. A single tuber was harvested from each plant Dec. 1991 and bulked by family. Tubers were shipped to Presque Isle, Maine, planted and harvested during Summer 1992. In each family the first 12 hills that produced at least nine seed pieces were saved for this study.

In 1993 tubers were planted in Presque Isle, Maine, in a randomized complete block design consisting of two replications of three hills per clone. An additional maintenance planting of three hills per clone was also planted. Tubers were planted 27 May on a Caribou gravelly loam soil (fine-loamy, mixed, frigid Typic Haplorthod). On 2 Sept., tubers were dug with a single-row digger and 25 medium to large size tubers were hand harvested from each plot. Following harvest, tubers were placed at $4{ }^{\circ} \mathrm{C}$, $95 \%$ relative humidity storage and transported to Beltsville, Md., in November.

Before evaluation, tubers were removed from cold storage and allowed to warm overnight to reduce condensation. Tubers were sliced in half from the apical to the distal end, blotted dry, and evaluated for yellow-flesh intensity using a Colorguard reflectance colorimeter (Colorguard System 1000; BYK-Gardner, Silver Spring, Md.) programmed to compute a yellow-intensity index, YI E-313 (American Society for Testing Materials, 1991). Tuber samples were evaluated from 3 Feb. to 26 Apr. 1994.

An average YI E-313 value was computed for each plot. The average YI E-313 value was analyzed using Proc Mixed in SAS (Littell et al., 1996). Replications, male parent, female parent, male $x$ female parents, and individual clones within a family were all treated as random effects. Estimates of variance components and their standard errors were used to estimate narrow-sense heritability and compute an approximate standard error of this heritability estimate (Hallauer and Miranda , 1981):

$\mathrm{h}^{2}=4 \sigma_{\mathrm{m}}^{2} /\left[\sigma^{2} / \mathrm{rf}+4 \sigma_{\mathrm{mf}}^{2} / \mathrm{f}+4 \sigma_{\mathrm{m}}^{2}\right]$

and

$\operatorname{SE}\left(h^{2}\right)=4 \operatorname{SE}\left(\sigma_{m}^{2}\right) /\left[\sigma^{2} / \mathrm{rf}+4 \sigma_{\mathrm{m} f}^{2} / \mathrm{f}+4 \sigma_{\mathrm{m}}^{2}\right]$

where $\sigma_{\mathrm{m}}^{2}=$ male variance $\sigma_{\mathrm{f}}^{2}=$ female variance, $\sigma_{\mathrm{mf}}^{2}=$ male $\mathrm{x}$ female variance, $r=$ number of replications, $f=$ number of female parents, $\mathrm{m}=$ number of male parents
Two independent estimates of narrow-sense heritability can be obtained from the general equations above by interchanging the male and female variances, and the number of male and female parents (Miranda and Hallauer, 1981).

\section{Results and Discussion}

The average yellow-flesh intensity of the 30 diploid potato families as measured by the YI E-313 index ranged from 45.7 to 71.8 (Table 1). Tuber flesh colors from cream to light yellow occur when the YI E-313 index ranges from the mid-40s to the low 50s, moderate yellow-flesh colors occur when the YI E-313 index ranges from the mid-50s to low 60s, and deep yellow- to almost orange-flesh colors occur when the YIE-313 index ranges from the mid-60s to the low 70s. Tuber flesh color in parents BD001-1, BD016-1, BD042-1, and BD057-1 was white to cream. Tuber flesh color in BD035-2, BD055-3, and BD065-3 was deep yellow to almost orange. Tuber flesh color in the remaining parental clones was moderately yellow. In general, for any given parent, mean yellow-flesh intensity in the offspring was less if the other parent was white to cream fleshed, and greater if the other parent was deep yellow fleshed. There were only two exceptions to this trend: BD024-2 x BD035-2 and BD057-1 x BD035-2. The cross BD057-1 x BD035-2, which was a cross between whitefleshed and deep yellow-fleshed parents, produced offspring as deeply yellow fleshed as the offspring of cross BD055-3 $\mathrm{x}$ BD035-2, a cross between two deeply yellow-fleshed parents. The cross BD024-2 x BD035-2, which was a cross between moderately yellow-fleshed and deeply yellow-fleshed parents produced offspring less deeply yellow fleshed than the offspring of crosses BD024-2 x BD023-2 and BD024-2 x BD072-3, which were crosses of two moderately yellow-fleshed parents. In the study conducted by Haynes et al. (1996), the average YI E-313 index measurement for 'Yukon Gold' across three locations in 2 years in the northeastern United States was 53.8, with a range of 50.2 to 56.6. Thus, the average yellow-flesh intensity in many of these diploid potato families was much higher than in 'Yukon Gold', the current standard yellow-flesh cultivar.

There were significant differences among families for the intensity of yellow flesh (Table 2). However, when the family source of variation was partitioned further into components due to male and female parents, and male $x$ female combinations, none of the components were significant. From a statistical standpoint, this lack of significance may have been due to the fewer degrees of freedom available for testing these individual components as compared to the overall family source of variation. It may also have resulted because both the male and female components of variance were of equal magnitude, and thus, the

Table 1. Mean ${ }^{\mathrm{z}}$ yellow-flesh intensity as measured by the YI E-313 index of 30 diploid potato (S. phureja-S. stenotomum) families grown in Presque Isle, Maine, in 1993.

\begin{tabular}{|c|c|c|c|c|c|c|}
\hline \multirow[b]{2}{*}{ Male parent } & \multicolumn{5}{|c|}{ Female parent } & \multirow[b]{2}{*}{ Mean } \\
\hline & BD007-2 & BD016-1 & BD024-2 & BD055-3 & $\overline{B D 057-1}$ & \\
\hline$\overline{\text { BD001-1 }}$ & 59.5 & 53.6 & 60.0 & 67.9 & 54.4 & 59.1 \\
\hline BD023-2 & 66.0 & 56.5 & 69.0 & 71.0 & 58.5 & 64.2 \\
\hline BD035-2 & 67.2 & 55.2 & 62.3 & 71.2 & 71.7 & 65.5 \\
\hline BD042-1 & 51.8 & 46.8 & 53.7 & 59.3 & 45.7 & 51.5 \\
\hline BD065-3 & 67.6 & 59.2 & 70.2 & 71.8 & 66.0 & 67.0 \\
\hline BD072-3 & 63.6 & 55.9 & 65.3 & 68.7 & 58.9 & 62.5 \\
\hline Mean & 62.6 & 54.5 & 63.4 & 68.3 & 59.2 & \\
\hline
\end{tabular}

${ }^{\mathrm{z}}$ Mean of each family based on $\approx 25$ tubers for each of 12 full-sibs per family. 
Table 2. Analysis of variance estimates of average YIE-313 index for 30 diploid potato (Solanum phureja-S. stenotomum) families grown in Presque Isle, Maine, in 1993.

\begin{tabular}{lcccc}
\hline \hline Source & Variance & $\mathrm{SE}^{\mathrm{z}}$ & $\mathrm{Z}^{\mathrm{y}}$ & $P>|\mathrm{Z}|$ \\
\hline Rep & 0.2 & 0.3 & 0.64 & 0.52 \\
Families & 46.0 & 13.7 & 3.36 & $<0.01$ \\
Male & 28.4 & 18.6 & 1.52 & 0.13 \\
Female & 27.0 & 19.7 & 1.37 & 0.17 \\
Male x female & 0 & --- & --- & --- \\
Clones (male x female) & 49.5 & 4.4 & 11.24 & $<0.01$ \\
Error & 6.1 & 0.5 & &
\end{tabular}

${ }^{\mathrm{z}_{\mathrm{SE}}}$ of the variance estimated.

${ }^{\mathrm{y}}$ Standard normal deviate.

variance of either of these components represented only approximately half of the total family source of variance. From the crossing standpoint, this lack of significance may also have been due to the fact that the full range of flesh colors from almost white to deep yellow occurred among both the male and female parents. If the male parents had all been of one flesh color and the female parents of the other flesh color, the results may have been different. The only significant source of variation in this study was due to clones within a family (i.e., full-sibs). From the estimates of the variance components and their standard errors (Table 2), estimates of narrow-sense heritability based on either the male variance or the female variance were computed as 0.99 with a SE of 0.65 or 0.72 , respectively. Such a high estimate of narrow-sense heritability would be expected when the trait is due to a single dominant gene (Fruwirth, 1912) for which there is little genotype $\times$ environment interaction (Haynes et al., 1996).

It is unknown at this point whether the greater intensity of yellow-flesh of some clones in this diploid population as compared to tetraploid potatoes is due to a greater concentration of color imparting carotenoids, the presence of additional carotenoids not found in the tetraploids, a combination of both of these possible factors, or tuber size per se. Diploid potatoes are much smaller than tetraploid potatoes. In the tetraploid potato clones evaluated for yellow-flesh intensity by Haynes et al. (1994), smaller potatoes had a greater yellow-flesh intensity than larger tubers within a given clone. Work is currently underway to analyze the tubers from this diploid population for carotenoid content. Tetraploid $x$ diploid crosses have already been made between these diploid yellow-fleshed clones and tetraploid clones to enhance the intensity of yellow-flesh in the tetraploid potato population. This diploid population represents an important germplasm source for enhancing the intensity of the yellow-flesh trait in tetraploid potatoes, and may even lead one day to the development of diploid yellow-fleshed potato cultivars for specialty markets.

\section{Literature Cited}

American Society for Testing Materials. 1991. ASTM standards on color and appearance measurement. 3rd ed. Amer. Soc. Testing Materials, Philadelphia.

Black, W. 1930. Notes on the progenies of various potato hybrids. J. Genet. 22:27-43.

Bonierbale, M.W., R.L. Plaisted, and S.D. Tanksley. 1988. RFLP maps based on a common set of clones reveal modes of chromosomal evolution in potato and tomato. Genetics 120:1095-1103.

Brown, C.R., C.G. Edwards, C.-P. Yang, and B.B. Dean. 1993. Orange flesh trait in potato: Inheritance and carotenoid content. J. Amer. Soc. Hort. Sci. 118:145-150.
Chase, R.W., N.R. Thompson, R.B. Kitchen, G.H. Silva, R. Hammerschmidt, and D.S. Douches. 1992. Michigold: A yellowfleshed potato cultivar for fresh market. Amer. Potato J. 69:629-634. Cipar, M.S., D. Hunter, P. Porter, and G. Henderson. 1990. Norwis: A new potato variety combining chipping quality, wide adaptation, disease resistance, and high yield. Amer. Potato J. 67:371-379.

Coffin, R., R. Chase, N. Thompson, G. Johnston, A. McKeown, M.K. Keenan, D. Craven, R. Kitchen, J. Wilson, and R.Y. Yada. 1989. Saginaw Gold: A yellow-fleshed potato cultivar with medium-high specific gravity and excellent chip and french fry quality after storage. Amer. Potato J. 66:303-313.

Coffin, R., G.R. Johnston, A. McKeown, R. Tarn, J. Wilson, M. Fitts, M.K. Keenan, L. Reynolds, and B. Langenberg. 1987. Red Gold: A yellow-fleshed red skinned potato cultivar with short dormancy and high tuber set. Amer. Potato J. 65:49-55.

Coffin, R., G.R. Johnston, A. McKeown, J. Wilson, M.K. Keenan, B. Langenberg, E. Knibbe, and L. Reynolds. 1988. Rose Gold: A yellowfleshed, pink-red skinned, tablestock cultivar with short dormancy and full season maturity. Amer. Potato J. 65:325-332.

Comstock, R.E. and H.F. Robinson. 1948. The components of genetic variance in populations of biparental progenies and their use in estimating the average degree of dominance. Biometrics 4:254-266.

Engel, K.H. 1957. Grunlegende Fragen zu einem schema fur arbeiten mit inzuchten bei Kartoffeln. Zuchter 27:98-124.

Fruwirth, C. 1912. Zur Zuchtung der Kartoffel. Dtsch. Landw. Presse 39:551-552, 565-567.

Gross, J. 1991. Pigments in vegetables: Chlorophylls and carotenoids. Van Nostrand Reinhold, New York.

Hallauer, A.R. and J.B. Miranda. 1981. Quantitative genetics in maize breeding. Iowa State Univ. Press, Ames.

Haynes, F.L. 1972. The use of cultivated diploid Solanum species in potato breeding, p. 100-110. In: E.R. French (ed.). Prospects for the potato in the developing world. Intl. Potato Ctr. Symp. Lima, Peru, 1719 July.

Haynes, K.G., F.L. Haynes, and W.R. Henderson. 1989. Heritability of specific gravity of diploid potato under high temperature growing conditions. Crop Sci. 29:622-625.

Haynes, K.G. and F.L. Haynes. 1990. Selection for tuber characters can maintain high specific gravity in a diploid potato breeding population. HortScience 25:227-228.

Haynes, K.G., W.E. Potts, J.L. Chittams, and D.L. Fleck. 1994. Determining yellow-flesh intensity in potatoes. J. Amer. Soc. Hort. Sci. 119:1057-1059.

Haynes, K.G., J.B. Sieczka, M.R. Henninger, and D.L. Fleck. 1996. Clone $\times$ environment interactions for yellow-flesh intensity in tetraploid potatoes. J. Amer. Soc. Hort. Sci. 121:175-177.

Haynes, K.G., D.R. Wilson, and M.S. Kang. 1995. Genotype $\times$ environment interactions for specific gravity in diploid potatoes. Crop Sci. 35:977-981.

Iwanzik, W., M. Tevini, R. Stute, and R. Hilbert. 1983. Carotinoidgehalt und-zusammensetzung verschiedener deutscher Kartoffelsorten und deren Bedeutung fur die Fleischfarbe der Knolle. Potato Res. 26:149162.

Johnston, G.R. and R.G. Rowberry. 1981. Yukon Gold: A new yellowfleshed, medium-early high quality table and french fry cultivar. Amer. Potato J. 58:241-244.

Littell, R.C., G.A. Milliken, W.W. Stroup, and R.D. Wolfinger. 1996. SAS system for mixed models. SAS Inst. Inc., Cary, N.C.

National Potato Council. 1998. 1998 potato statistical yearbook. Natl. Potato Council, Englewood, Colo.

Reeves, A.F., R.E. Webb, D.C. Merriam, H.J. Murphy, F.E. Manzer, and R.H. True. 1980. Delta Gold: A new potato variety with yellow flesh, high solids and high quality for baking and processing. Amer. Potato J. 57:429-433.

Schick, R. 1956. Methoden und Probleme der Kartoffelzuchtung. Zber. dtsch. Akad. LandWiss. Berl. 5(29):1-40.

Zink, R. 1996. Looking to the future with yellow-fleshed potatoes. Valley Potato Grower. (October):24 